\title{
Roken en alcoholgebruik onder Nederlandse scholieren
}

\section{Ontwikkelingen in de afgelopen twintig jaar}

\author{
Marlous Tuithof · Saskia van Dorsselaer · Marieke Rombouts · Marloes Kleinjan · Karin Monshouwer
}

(C) The Author(s) 2020

Samenvatting De afgelopen decennia is sterk ingezet op het terugdringen van tabaks- en alcoholgebruik onder jongeren. Monitoring is belangrijk om te toetsen of uitgezet beleid gepaard gaat met het gewenste resultaat. Met gegevens van het Peilstationsonderzoek Scholieren wordt onderzocht hoe het tabaks- en alcoholgebruik onder scholieren van twaalf tot en met zestien jaar tussen 1999 en 2019 veranderd is, met specifieke aandacht voor (1) verschillen naar geslacht en leeftijd, en (2) veranderingen in de populatiesamenstelling over tijd. Roken en alcoholgebruik zijn in deze periode sterk gedaald (lifetime-prevalentie roken van $53,9 \%$ in 1999 naar $17,0 \%$ in 2019 ; lifetime-prevalentie alcoholgebruik van $71,9 \%$ naar $46,6 \%$ ). De daling heeft zich vooral tot 2015 voorgedaan en lijkt sindsdien tot stilstand gekomen. De trends zijn voor jongens en meisjes vrijwel hetzelfde, maar de daling is voor jongere leeftijdsgroepen groter dan voor oudere leeftijdsgroepen. Ook na controle voor sociaal-demografische kenmerken bleef de daling in roken en alcoholgebruik bestaan. Daarnaast is het drinken van vijf glazen of meer bij één gelegenheid (bingedrinken) onder degenen die de afgelopen maand dronken van $64,1 \%$ in 2003 gestegen naar 70,6\% in 2019. Een nieuwe impuls

Bron: Peilstationsonderzoek Scholieren/Leefstijlmonitor, Trimbos-instituut in samenwerking met het RIVM. Het Peilstationsonderzoek Scholieren is uitgevoerd met financiering van het ministerie van Volksgezondheid, Welzijn en Sport.

M. Tuithof $(\varangle) \cdot$ S. van Dorsselaer · M. Rombouts .

M. Kleinjan · K. Monshouwer

Trimbos-instituut, Utrecht, Nederland

mtuithof@trimbos.nl

M. Kleinjan

Interdisciplinaire sociale wetenschap, afdeling Jeugdstudies,

Universiteit Utrecht, Utrecht, Nederland lijkt nodig om het gebruik van tabak en alcohol onder scholieren verder terug te dringen.

Trefwoorden trends - roken - alcoholgebruik · jongeren $\cdot$ Peilstationsonderzoek Scholieren

\section{Smoking and alcohol consumption among secondary school students Developments during the last twenty years}

Abstract In recent decades, strong efforts have been made to reduce smoking and alcohol consumption among secondary school students. Monitoring is important to test whether policies are accompanied by the desired result. With data from the Dutch National school survey, changes in smoking and alcohol consumption among students aged 12-16 between 1999 and 2019 are investigated, with focus on (1) gender and age differences; and (2) changes in population composition over time. The results show that smoking and alcohol consumption fell sharply during this period (lifetime prevalence smoking from $53.9 \%$ in 1999 to $17.0 \%$ in 2019 and of alcohol consumption from $71.9-46.6 \%$ ). The decline occurred mainly until 2015 and has since come to a standstill. The trends are largely similar for boys and girls, but the decline is greater for younger age groups than for older age groups. Even after correction for socio-demographic characteristics, the decrease in smoking and alcohol consumption continued. Moreover, drinking five or more glasses on one occasion (binge drinking) among those who drank in the past month has increased from $64.1 \%$ in 2003 to $70.6 \%$ in 2019 . A new impetus seems necessary to further reduce the use of alcohol and tobacco among students.

Keywords Trends · Smoking · Alcohol drinking · Adolescents · Cross-sectional studies 


\section{Inleiding}

In de afgelopen twee decennia is sterk ingezet op het terugdringen van tabaks- en alcoholgebruik onder jongeren. Zo zijn de risico's van roken en alcohol voor de ontwikkeling van jongeren via massamediale voorlichting uitgebreid onder de aandacht gebracht. Hierbij ging het over de schadelijkheid voor de hersenen en over andere gezondheidsproblemen, zoals het risico op verslaving [1-7]. Gebaseerd op wetenschappelijke inzichten is er tegelijkertijd veel nadruk gelegd op het informeren van ouders over de invloed die hun opvoedstijl heeft op het gedrag van hun kinderen en het belang van het stellen van regels $[8,9]$. Met de invoering van de nieuwe Drank- en Horecawet in 2013 hebben gemeenten een prominentere rol in alcoholpreventie gekregen. Ook werden gemeenten verantwoordelijk voor de controle op de in 2014 ingevoerde leeftijdsverhoging van zestien naar achttien jaar voor het kopen van tabak en alcohol. De leeftijdsverhoging ging gepaard met de meerjarige NIX18campagne, waarbij de nadruk lag op het versterken van de sociale norm 'Niet roken en niet drinken onder de 18'. Op het terrein van de tabaksontmoediging zijn er accijnsverhogingen geweest, werden schoolpleinen rookvrij gemaakt en is er aandacht geweest voor het inperken van de beschikbaarheid en zichtbaarheid van tabak [10, 11]. Ten slotte vormen jongeren een belangrijke doelgroep in het Nationale Preventieakkoord uit 2018 [12]. Hierin zijn doelstellingen en activiteiten geformuleerd voor het terugdringen van roken en drinken door jongeren. Dit is slechts een greep uit de maatregelen - er hebben zich nog meer wijzigingen in preventie en beleid voorgedaan.

Ook in andere Europese landen zijn maatregelen ingevoerd om het gebruik van alcohol en tabak terug te dringen. Voor tabak heeft een meerderheid van de Europese landen, waaronder Nederland, zich bijvoorbeeld gecommitteerd aan het Framework Convention on Tobacco Control (FCTC)-verdrag, waarbij tabaksontmoediging centraal staat [13]. Uit Europees onderzoek onder scholieren blijkt dat de ingevoerde maatregelen gepaard gaan met een sterke daling in het gebruik van tabak in elk van de vijf onderscheiden regio's (Noord, Zuid, West, Oost en de Balkan) [14]. Ook voor alcohol lijken de trends, met uitzondering van de Balkan, vergelijkbaar in de verschillende regio's, dat wil zeggen een dalende trend na een piek rond 2007 [14].

Om in beeld te krijgen of de maatregelen ook in Nederland gepaard gaan met het beoogde doel - een daling in het gebruik van tabak en alcohol door jongeren -, is het cruciaal om regelmatig en systematisch te meten hoe het gebruik van deze middelen zich ontwikkelt. Hierbij zijn ten minste twee punten van belang. Ten eerste moet er aandacht zijn voor verschillen naar geslacht en leeftijd. Internationaal onderzoek suggereert dat de trend in tabaks- en alcoholgebruik zich onder jongens en meisjes verschillend ontwikkelt
[14]. Voor riskant alcoholgebruik zijn er bijvoorbeeld aanwijzingen dat onder Europese jongeren, meisjes hun 'achterstand' op jongens inlopen [14]. Voor een juiste inzet en eventuele toespitsing van preventiemaatregelen is dit belangrijke informatie. Ook wat betreft leeftijd is een goed beeld over de tijd belangrijk. Zo liet onderzoek naar de ophoging van de leeftijdsgrens voor de verkoop van alcohol zien dat dit sterkere effecten heeft op het gebruik onder jongere leeftijdsgroepen, dan onder oudere leeftijdsgroepen [15, 16]. Ten tweede is het van belang om rekening te houden met de veranderingen die de afgelopen decennia in de opbouw van de samenleving hebben plaatsgevonden. Uit cijfers van het Centraal Bureau voor de Statistiek (CBS) blijkt dat het opleidingsniveau onder jongeren is toegenomen, net als het aantal jongeren met een migratieachtergrond [17]. Beide factoren hangen samen met tabaks- en alcoholgebruik [18-20]. Om vast te stellen in hoeverre de veranderingen in roken en alcoholgebruik onder scholieren verklaard kunnen worden uit deze veranderingen in de populatiesamenstelling is het van belang om ook trendcijfers te berekenen waarbij hiervoor is gecorrigeerd.

$\mathrm{Al}$ sinds de jaren tachtig voert het Trimbos-instituut elke vier jaar het Peilstationsonderzoek Scholieren uit om onder andere het gebruik van tabak en alcohol onder scholieren in het regulier onderwijs te peilen [21]. Doel van dit artikel is om na te gaan in hoeverre de preventieve en beleidsmaatregelen van de afgelopen twee decennia gepaard zijn gegaan met de gewenste ontwikkelingen in tabaks- en alcoholgebruik onder jongeren. Daartoe worden de trends beschreven in de prevalentie van roken en alcoholgebruik en wordt nagegaan of de ontwikkelingen anders zijn voor jongens en meisjes en voor de verschillende leeftijdsgroepen. Vervolgens wordt gekeken in hoeverre deze ontwikkelingen te verklaren zijn door veranderingen in de samenstelling van de populatie, wat betreft opleidingsniveau en migratieachtergrond.

\section{Methode}

We maken gebruik van de gegevens van zes metingen van het Peilstationsonderzoek in de periode van 1999 tot en met 2019. Het Peilstationsonderzoek vindt plaats in representatieve steekproeven van scholieren in groep 7 en 8 van het reguliere basisonderwijs en alle scholieren in het reguliere voortgezet onderwijs (vmbo, havo, vwo). In 2014 is het Peilstationsonderzoek opgenomen in de Leefstijlmonitor (LSM) en verantwoordelijk voor de landelijke kerncijfers over genotmiddelengebruik van jongeren in de leeftijd van twaalf tot en met zestien jaar [22]. Dit artikel richt zich alleen op leerlingen uit het voortgezet onderwijs en, net als het landelijke rapport, op leerlingen van twaalf tot en met zestien jaar [21].

In 1999 werd de dataverzameling uitgevoerd door de GGD'en, die voor een goede spreiding van de scholen over hun werkgebied zorgden. Sinds 2003 is een 
Tabel 1 Sociaal-demografische kenmerken van de steekproef (twaalf tot en met zestien jaar) naar meting in ongewogen aantallen en gewogen percentages

\begin{tabular}{|c|c|c|c|c|c|c|c|c|c|c|c|c|}
\hline & \multicolumn{2}{|l|}{1999} & \multicolumn{2}{|l|}{2003} & \multicolumn{2}{|l|}{2007} & \multicolumn{2}{|l|}{2011} & \multicolumn{2}{|l|}{2015} & \multicolumn{2}{|l|}{2019} \\
\hline & $n$ & $\%$ & $n$ & $\%$ & $n$ & $\%$ & $n$ & $\%$ & $n$ & $\%$ & $n$ & $\%$ \\
\hline Totaal & 6.248 & & 7.359 & & 6.980 & & 7.076 & & 6.714 & & 5.587 & \\
\hline \multicolumn{13}{|l|}{ Geslacht } \\
\hline Jongen & 2.982 & 48,5 & 3.435 & 51,2 & 3.413 & 51,2 & 3.593 & 51,2 & 3.392 & 51,1 & 2.872 & 51,2 \\
\hline Meisje & 3.238 & 51,5 & 3.924 & 48,8 & 3.567 & 48,8 & 3.483 & 48,8 & 3.322 & 48,9 & 2.711 & 48,8 \\
\hline \multicolumn{13}{|l|}{ Leeftijd } \\
\hline 12 jaar & 869 & 16,0 & 1.319 & 17,2 & 1.013 & 14,9 & 1.114 & 16,3 & 1.256 & 19,2 & 1.232 & 19,7 \\
\hline 13 jaar & 1.236 & 22,3 & 1.844 & 22,9 & 1.694 & 24,1 & 1.660 & 23,5 & 1.520 & 21,7 & 1.219 & 21,1 \\
\hline 14 jaar & 1.264 & 24,1 & 1.775 & 22,2 & 1.663 & 22,6 & 1.710 & 22,5 & 1.573 & 22,0 & 1.273 & 22,4 \\
\hline 15 jaar & 1.640 & 22,8 & 1.547 & 22,6 & 1.498 & 21,7 & 1.495 & 21,4 & 1.435 & 21,7 & 1.093 & 21,8 \\
\hline 16 jaar & 1.239 & 14,7 & 874 & 15,0 & 1.112 & 16,7 & 1.097 & 16,3 & 930 & 15,4 & 770 & 15,0 \\
\hline \multicolumn{13}{|l|}{ Schoolniveau ${ }^{a}$} \\
\hline Vmbo-b & - & - & 2.032 & 26,1 & 1.634 & 21,9 & 1.617 & 21,5 & 1.378 & 19,3 & 1.100 & 19,4 \\
\hline Vmbo-t & - & - & 2.210 & 29,9 & 2.170 & 31,2 & 2.161 & 29,2 & 2.170 & 29,9 & 1.661 & 27,9 \\
\hline Havo & - & - & 1.725 & 26,0 & 1.716 & 26,9 & 1.468 & 25,5 & 1.724 & 26,9 & 1.414 & 25,6 \\
\hline Vwo & - & - & 1.275 & 18,0 & 1.460 & 20,0 & 1.807 & 23,9 & 1.442 & 23,9 & 1.412 & 27,1 \\
\hline \multicolumn{13}{|c|}{ Migratieachtergrond ${ }^{a}$} \\
\hline Nederlands & - & - & 5.834 & 79,6 & 5.657 & 82,0 & 5.662 & 81,3 & 5.362 & 79,8 & 4.151 & 74,1 \\
\hline Westers & - & - & 446 & 6,0 & 428 & 6,1 & 438 & 6,0 & 371 & 5,7 & 408 & 7,5 \\
\hline Niet-westers & - & - & 1.074 & 14,4 & 867 & 11,9 & 958 & 12,7 & 972 & 14,5 & 1.012 & 18,4 \\
\hline
\end{tabular}

steekproeftrekking in twee fasen toegepast. In fase 1 vond een random selectie van de scholen plaats, waarbij gestratificeerd werd naar GGD-regio en stedelijkheid. Deze scholen werden door de GGD of het Trimbos-instituut benaderd voor deelname (zie het rapport voor meer informatie [21]). De respons van scholen in het voortgezet onderwijs varieerde in de periode $2003-2019$ van $40-55 \%$. Vooral de laatste jaren is het moeilijker om scholen tot deelname aan het onderzoek aan te zetten. De voornaamste redenen voor non-respons zijn dat scholen aangeven al betrokken te zijn bij ander onderzoek of te vaak benaderd worden voor onderzoek. In fase 2 wordt bij de deelnemende scholen een willekeurige steekproef van twee of drie klassen uit alle leerjaren getrokken. Vervolgens vindt in oktober/november een klassikale afname plaats onder leiding van een onderzoeksassistent van het Trimbos-instituut. Tot en met 2011 werd gebruikgemaakt van schriftelijke vragenlijsten, in 2015 en 2019 betreft het zo veel mogelijk digitale vragenlijsten. Leerlingen en hun ouders kregen vooraf informatie over het onderzoek en uitleg over de anonimiteit. Deelname was vrijwillig en ouders hadden de mogelijkheid hun kind af te melden voor deelname. De onderzoeksassistenten registreerden per klas de non-respons. De nonrespons op leerlingniveau was laag (tussen de 5 en 8\%) en kwam meestal door afwezigheid wegens ziekte. $\mathrm{Na}$ herweging op stedelijkheid, geslacht, leerjaar en schoolniveau was de verdeling in de steekproef na- genoeg gelijk aan de landelijke verdeling volgens het CBS in het jaar van het onderzoek (zie tab. 1).

In 2019 is het onderzoek goedgekeurd door de ethische toetsingscommissie van het Trimbos-instituut.

\section{Meetinstrumenten}

De beschrijving van de meetinstrumenten beperkt zich tot de kernvariabelen met betrekking tot roken, alcoholgebruik en sociaal-demografische kenmerken die meegenomen zijn in dit artikel. In het Peilstationsonderzoek Scholieren worden meer middelen onderzocht - zie het rapport voor een compleet overzicht [21].

\section{Roken}

Aan scholieren is gevraagd of zij ooit in hun leven (ten minste een paar trekjes) en in de maand voorafgaand aan het onderzoek hebben gerookt. Ook is gevraagd hoe vaak zij momenteel roken, waarop de variabele dagelijks roken is gebaseerd.

\section{Alcoholgebruik}

Eerst is gevraagd of scholieren ooit in hun leven en in de maand voorafgaand aan het onderzoek alcohol hebben gedronken. Daarnaast wordt sinds 2003 gevraagd of scholieren in de afgelopen maand weleens bij één gelegenheid vijf glazen of meer hebben gedronken (het zogenaamde bingedrinken). Vóór 2003 
werd bingedrinken op een andere wijze gemeten waardoor de gegevens niet vergelijkbaar zijn.

\section{Sociaal-demografische kenmerken}

Leeftijd is bepaald door het verschil tussen de onderzoeksdatum en de geboortemaand en het geboortejaar te berekenen. Ook is gevraagd naar het geslacht van de leerling. Er worden vier schoolniveaus onderscheiden: vmbo-beroepsgerichte of kaderberoepsgerichte leerweg (vmbo-b), vmbo theoretische of gemengde leerweg (vmbo-t), havo en vwo. Bij een combinatie van twee schoolniveaus is een leerling bij het laagste schoolniveau ingedeeld. In het Peilstationsonderzoek uit 1999 ontbreekt informatie over het schoolniveau omdat toen in de eerste twee leerjaren niet naar schoolniveau werd gevraagd. Leerlingen zijn op basis van het geboorteland van henzelf en hun biologische ouders wat betreft migratieachtergrond in drie categorieën ingedeeld: Nederlandse achtergrond, en westerse en niet-westerse migratieachtergrond. Hierbij is de CBS-definitie gehanteerd. Deze informatie ontbreekt voor 1999, omdat toen geen onderscheid werd gemaakt in een westerse of niet-westerse migratieachtergrond.

\section{Data-analyse}

Voor het in beeld brengen van de steekproefsamenstelling en de prevalenties zijn beschrijvende analyses uitgevoerd. Significante veranderingen zijn getoetst met (multinomiale) logistische regressieanalyses. Bij de prevalenties zijn daarbij post-hoc pairwise comparisons uitgevoerd (met een bonferronicorrectie voor het aantal toetsen), zodat de verschillende onderzoeken met elkaar vergeleken konden worden. Verschillen in de trends naar geslacht en leeftijd zijn geanalyseerd met interactie-effecten in univariate logistische regressieanalyses. Het significantieniveau is vastgesteld op $p<0,05$. Ten slotte is met (multivariate) logistische regressiemodellen gekeken of de trends in roken en alcoholgebruik sinds 2003 verklaard kunnen worden door veranderingen in algemene kenmerken van de scholieren, zoals schoolniveau en migratieachtergrond. Model 1 betreft steeds een univariate logistische regressieanalyse met 2003 als referentiejaar. In model 2 worden dezelfde analyses herhaald, maar nu met correctie voor geslacht, leeftijd, schoolniveau en migratieachtergrond. In deze analyses kon de meting van 1999 niet meegenomen worden omdat het schoolniveau en de migratieachtergrond toen op een andere wijze werden vastgesteld.

De data werden geanalyseerd met Stata (versie 12.1). Dit pakket houdt rekening met zowel weging als clustering van de data (leerlingen uit dezelfde klas/ school delen kenmerken met elkaar).

\section{Resultaten}

De grootte van de steekproef varieert van 5.587 scholieren in 2019 tot 7.359 scholieren in 2003. Multinomiale logistische regressiemodellen laten zien dat de steekproefopbouw wat betreft geslacht en leeftijd sinds 1999 niet is veranderd. Vergeleken met 2003 is het aandeel vwo-scholieren in 2019 toegenomen, net als het aandeel leerlingen met een westerse migratieachtergrond (tab. 1).

\section{Roken}

Het aantal leerlingen van twaalf tot en met zestien jaar dat ooit gerookt heeft, is fors gedaald: van $53,9 \%$ in 1999 naar $17,0 \%$ in 2019 (tab. 2). De daling is in alle opeenvolgende Peilstationsonderzoeken te zien (alleen in 2011 niet-significant). De maandprevalentie van roken is in $2019(7,7 \%)$ ook flink lager dan in 1999 (26,0\%). Deze daling heeft zich vooral voorgedaan tussen 1999-2003 en 2011-2015. Sindsdien is er alleen nog een lichte (niet-significante) daling geweest. De prevalentie van dagelijks roken vertoont een vergelijkbaar patroon als de maandprevalentie van roken.

Door de jaren heen zijn er geen grote verschillen tussen jongens en meisjes zichtbaar in de prevalentie van roken (tab. 2). Ook is de daling in de lifetime- en maandprevalentie van roken voor jongens en meisjes vergelijkbaar geweest, behalve in 2003. Uit de interactieanalyses blijkt dat de daling in de maandprevalentie in dat jaar sterker was voor jongens. Uitsplitsing naar leeftijd laat zien dat de algemene trend in grote lijnen ook te zien is onder alle leeftijden (fig. 1). Wel laten de interactieanalyses zien dat de daling significant sterker was voor de twaalfjarigen, dan voor de veertien-, vijftien- en zestienjarigen.

\section{Alcoholgebruik}

Vergeleken met 1999 (71,9\%) hebben in 2019 beduidend minder scholieren in het voortgezet onderwijs ervaring met het gebruik van alcohol (46,6\%; tab. 2). In 2003 lag het percentage met $84,2 \%$ zelfs nog hoger dan in 1999. De daling die na 2003 is ingezet vindt vooral plaats tussen 2011 (66,2\%) en 2015 (45,4\%). In het daaropvolgende Peilstationsonderzoek (2019) blijft het percentage vrijwel gelijk. Ook de daling in het gebruik van alcohol in de afgelopen maand lijkt sinds 2015 gestagneerd. In zowel 2015 als 2019 heeft ongeveer een kwart van de twaalf- tot en met zestienjarige scholieren in de afgelopen maand alcohol gedronken.

De verschillen tussen jongens en meisjes zijn over het algemeen niet groot. In 2019 is voor geen enkele uitkomstmaat sprake van een significant verschil tussen jongens en meisjes (tab. 2).

De daling in de prevalentie is vergelijkbaar geweest voor jongens en meisjes. Na uitsplitsing van de trends naar leeftijd blijkt dat de daling tussen 2003 en 2015 


\section{Wetenschappelijk artikel}

Tabel 2 Prevalentie van roken en alcoholgebruik naar geslacht en onderzoeksjaar in gewogen percentages

\begin{tabular}{|c|c|c|c|c|c|c|}
\hline & 1999 & 2003 & 2007 & 2011 & 2015 & 2019 \\
\hline \multicolumn{7}{|l|}{ Roken } \\
\hline \multicolumn{7}{|l|}{ Ooit } \\
\hline - Totaal & 53,9 & $43,7^{b}$ & $36,9^{b}$ & 33,2 & $22,8^{b}$ & $17,0^{b}$ \\
\hline - Jongens & 55,2 & $43,1^{b}$ & $36,1^{b}$ & 35,2 & $24,3^{b}$ & $17,4^{b}$ \\
\hline - Meisjes & 52,7 & $44,3^{b}$ & $37,7^{b}$ & $31,1^{b}$ & $21,2^{b}$ & 16,5 \\
\hline \multicolumn{7}{|c|}{ Laatste maand } \\
\hline - Totaal & 26,0 & $18,9^{b}$ & 17,1 & 16,9 & $10,6^{b}$ & 7,7 \\
\hline - Jongens & 25,2 & $16,4^{b}$ & 16,6 & 17,5 & $11,0^{b}$ & 8,1 \\
\hline - Meisjes & 26,6 & 21,5 & 17,6 & 16,3 & $10,2^{b}$ & 7,3 \\
\hline \multicolumn{7}{|l|}{ Dagelijks } \\
\hline - Totaal & 13,0 & $8,4^{b}$ & 6,4 & 6,3 & $3,1^{b}$ & 1,8 \\
\hline - Jongens & 13,1 & $7,4^{b}$ & 6,4 & 7,1 & $3,6^{b}$ & 2,0 \\
\hline - Meisjes & 12,9 & 9,4 & 6,5 & 5,5 & $2,6^{b}$ & 1,6 \\
\hline \multicolumn{7}{|l|}{ Alcohol } \\
\hline \multicolumn{7}{|l|}{ Ooit } \\
\hline - Totaal & 71,9 & $84,2^{b}$ & $77,5^{b}$ & $66,2^{\mathbf{b}}$ & $45,4^{b}$ & 46,6 \\
\hline - Jongens & 76,2 & $85,3^{b}$ & $79,6^{\mathbf{b}}$ & $69,0^{b}$ & $48,1^{b}$ & 47,8 \\
\hline - Meisjes & 68,0 & $83,0^{b}$ & $75,2^{b}$ & $63,3^{b}$ & $42,7^{b}$ & 45,4 \\
\hline \multicolumn{7}{|c|}{ Laatste maand } \\
\hline - Totaal & 51,2 & 57,1 & $47,2^{b}$ & $37,8^{b}$ & $25,5^{b}$ & 26,2 \\
\hline - Jongens & 56,1 & 58,2 & $48,0^{b}$ & $38,6^{b}$ & $26,3^{b}$ & 26,5 \\
\hline - Meisjes & 46,7 & $56,0^{b}$ & $46,5^{b}$ & $37,1^{b}$ & $24,7^{b}$ & 26,0 \\
\hline \multicolumn{7}{|c|}{ Laatste maand bingedrinken } \\
\hline - Totaal & - & 36,5 & 31,3 & $24,7^{b}$ & $17,8^{b}$ & 18,5 \\
\hline - Jongens & - & 38,1 & 32,6 & 26,0 & $18,9^{b}$ & 18,1 \\
\hline - Meisjes & - & 34,9 & 29,9 & $23,3^{b}$ & $16,6^{b}$ & 19,0 \\
\hline \multicolumn{7}{|c|}{ Bingedrinken onder drinkers ${ }^{\mathrm{a}}$} \\
\hline - Totaal & - & 64,1 & 65,8 & 65,0 & 69,5 & 70,6 \\
\hline - Jongens & - & 65,7 & 67,4 & 67,3 & 71,7 & 68,2 \\
\hline - Meisjes & - & 62,5 & 64,0 & 62,4 & 67,1 & 73,1 \\
\hline \multicolumn{7}{|c|}{$\begin{array}{l}\text { aScholieren die de afgelopen maand alcohol hebben gedronken } \\
\text { bVerschillend van het voorgaande Peilstationsonderzoek }\end{array}$} \\
\hline
\end{tabular}

het sterkst is voor jongere leeftijdsgroepen (fig. 2). De interactieanalyses lieten zien dat de daling voor de twaalfjarigen sterker was dan voor de oudere leeftijdsgroepen; dit betreft vooral de vijftien- en zestienjarigen.

De maandprevalentie van bingedrinken wordt in tab. 2 gepresenteerd als percentage van de totale groep scholieren van twaalf tot en met zestien jaar en als percentage van de scholieren die de afgelopen maand alcohol hebben gedronken (de 'drinkers'). De daling tussen 2007 en 2015 in de maandprevalentie van bingedrinken als percentage van alle scholieren lijkt sinds 2015 te zijn gestagneerd. Het bingedrinken onder de drinkers lijkt geleidelijk toe te nemen. Geen van de verschillen tussen de opeenvolgende Peilstationsonderzoeken is significant, maar in 2019 komt bingedrinken onder de drinkers vaker voor dan in 2003.

Door de jaren heen zijn de verschillen in bingedrinken tussen jongens en meisjes niet groot. De interac- tieanalyses laten zien dat de daling in bingedrinken als percentage van alle scholieren iets sterker is voor jongens dan voor meisjes, maar het verschil is net niet significant $(p=0,053)$. Uit deze analyses blijkt verder dat de toename van bingedrinken onder de drinkers significant sterker is voor meisjes dan voor jongens. Daarnaast blijkt dat de daling in bingedrinken in de totale groep sterker is voor de twaalfjarigen dan voor de veertien-, vijftien- en zestienjarigen. De stijging van bingedrinken onder de drinkers is juist het sterkst voor de veertien-, vijftien- en zestienjarigen (de prevalentiecijfers laten voor de twaalfjarigen een niet-significante daling zien).

\section{Multivariate toetsing}

Met (multivariate) logistische regressiemodellen is gekeken of de veranderingen in roken en alcoholgebruik sinds 2003 verklaard kunnen worden door veranderin- 
Figuur 1 Trend in de lifetime- en maandprevalentie van roken naar leeftijd (\%)

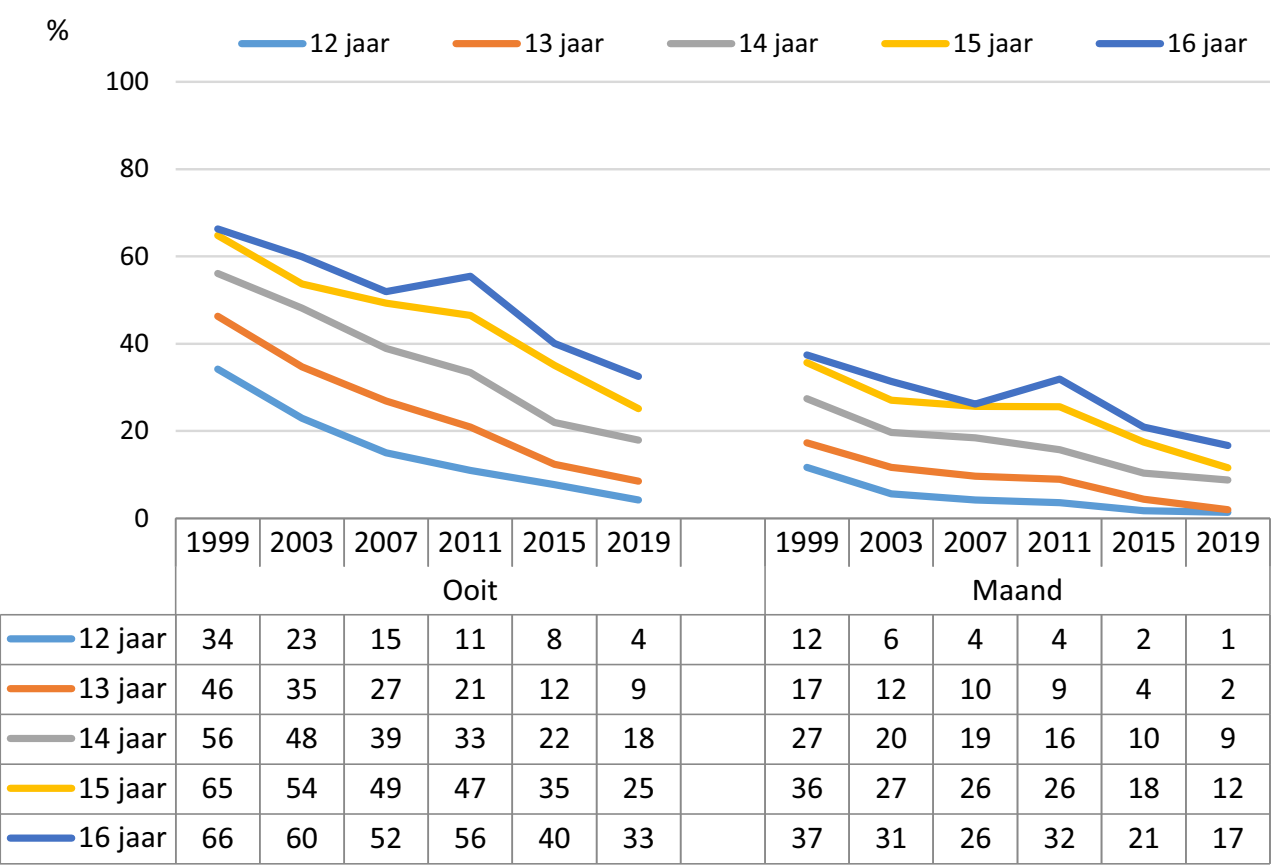

Figuur 2 Trend in de lifetime- en maandprevalentie van alcoholgebruik naar leeftijd (\%)

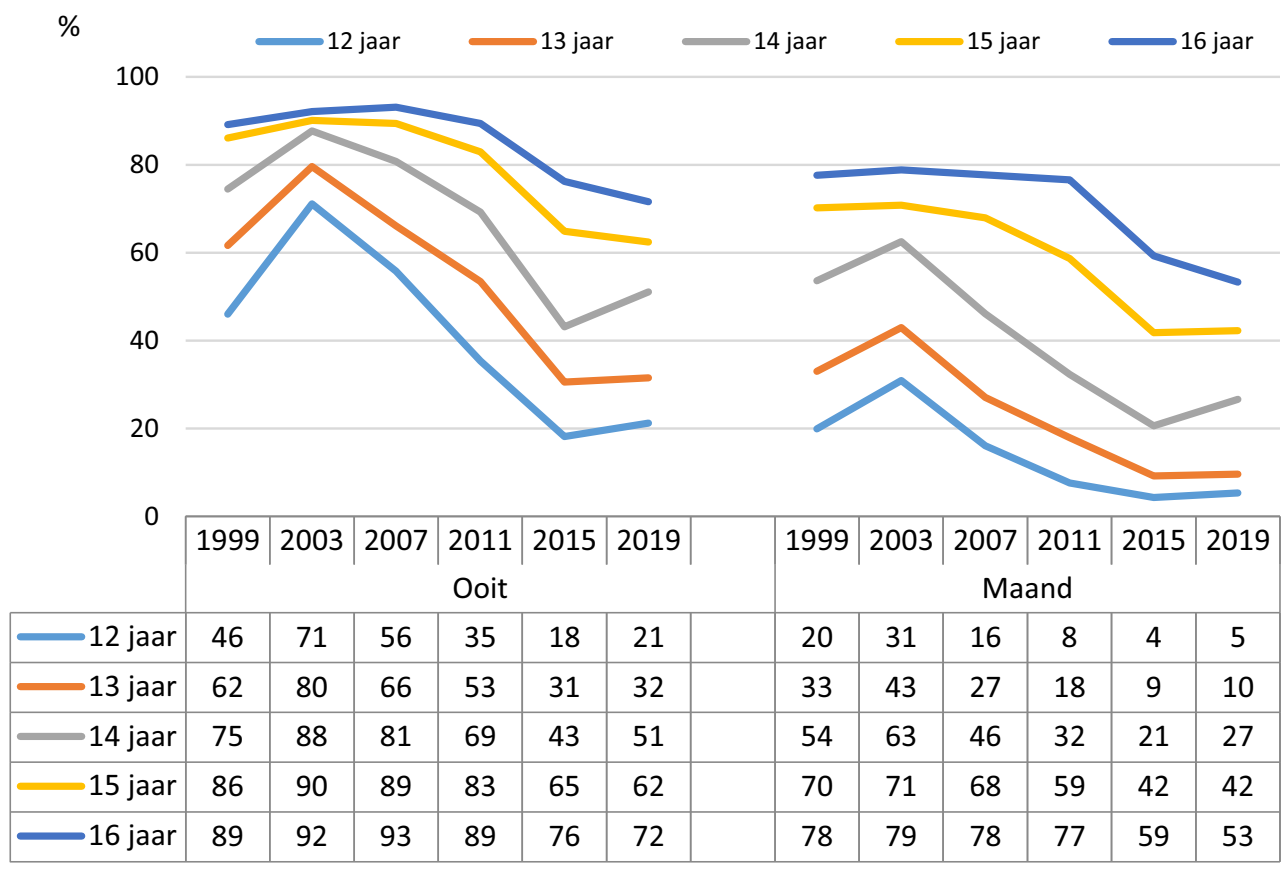

gen in algemene kenmerken van de scholieren. Zoals tab. 3 laat zien blijven de beschreven resultaten grotendeels overeind. Dat wil zeggen, model 1 (zonder correctie) en model 2 (met correctie voor geslacht, leeftijd, schoolniveau en migratieachtergrond) laten een vergelijkbare daling zien in de prevalentie van roken (lifetime, in de afgelopen maand en dagelijks roken) en alcoholgebruik (lifetime, in de afgelopen maand en bingedrinken). Ook de toename van bingedrinken onder de drinkers tussen 2003 en 2019 blijft staan, maar lijkt wel minder sterk na correctie voor steekproefkenmerken.

\section{Beschouwing}

\section{Belangrijkste bevindingen}

Met gegevens van zes metingen van het Peilstationsonderzoek is onderzocht hoe het gebruik van tabak en alcohol onder twaalf- tot en met zestienjarigen tussen 1999 en 2019 veranderd is. Uit de resultaten blijkt dat het gebruik van tabak en alcohol in de periode tot 2015 spectaculair gedaald is. Dit geldt ook voor de intensievere gebruikspatronen, zoals dagelijks roken en bingedrinken. Sinds 2015 lijkt de positieve trend gro- 
Tabel 3 Veranderingen in roken en alcoholgebruik in gewogen oddsratio's (OR) met 95\%-betrouwbaarheidsintervallen $(95 \%-B I)^{b}$

\begin{tabular}{|c|c|c|c|c|c|c|c|}
\hline & \multicolumn{3}{|l|}{ Roken } & \multicolumn{4}{|l|}{ Alcohol } \\
\hline & Ooit & Maand & Dagelijks & Ooit & Maand & Bingedrinken (totaal) & $\begin{array}{l}\text { Bingedrinken (drin- } \\
\text { kers) }\end{array}$ \\
\hline & OR (95\%-BI) & OR (95\%-BI) & OR (95\%-BI) & OR (95\%-BI) & OR (95\%-BI) & OR (95\%-BI) & OR (95\%-BI) \\
\hline \multicolumn{8}{|c|}{ Model 1} \\
\hline 2003 & Referentie & Referentie & Referentie & Referentie & Referentie & Referentie & Referentie \\
\hline 2007 & $\begin{array}{l}0,75^{\star \star \star} \\
(0,65-0,87)\end{array}$ & $\begin{array}{l}0,89 \\
(0,74-1,06)\end{array}$ & $\begin{array}{l}0,76^{\star} \\
(0,60-0,95)\end{array}$ & $\begin{array}{l}0,64^{\star \star \star} \\
(0,53-0,79)\end{array}$ & $\begin{array}{l}0,67^{\star \star \star} \\
(0,56-0,80)\end{array}$ & $\begin{array}{l}0,79^{\star *} \\
(0,66-0,94)\end{array}$ & $\begin{array}{l}1,08 \\
(0,92-1,26)\end{array}$ \\
\hline 2011 & $\begin{array}{l}0,64^{\star \star \star} \\
(0,55-0,75)\end{array}$ & $\begin{array}{l}0,87 \\
(0,73-1,05)\end{array}$ & $\begin{array}{l}0,74^{*} \\
(0,58-0,94)\end{array}$ & $\begin{array}{l}0,37^{\star \star \star} \\
(0,30-0,45)\end{array}$ & $\begin{array}{l}0,46^{\star \star \star} \\
(0,38-0,56)\end{array}$ & $\begin{array}{l}0,57^{\star \star \star} \\
(0,47-0,68)\end{array}$ & $\begin{array}{l}1,04 \\
(0,88-1,22)\end{array}$ \\
\hline 2015 & $\begin{array}{l}0,38^{\star \star \star} \\
(0,32-0,45)\end{array}$ & $\begin{array}{l}0,51^{\star \star \star} \\
(0,42-0,62)\end{array}$ & $\begin{array}{l}0,35^{\star \star \star} \\
(0,27-0,46)\end{array}$ & $\begin{array}{l}0,16^{\star \star \star} \\
(0,13-0,19)\end{array}$ & $\begin{array}{l}0,26^{\star \star \star} \\
(0,21-0,31)\end{array}$ & $\begin{array}{l}0,38^{\star \star \star} \\
(0,31-0,45)\end{array}$ & $\begin{array}{l}1,28^{\star} \\
(1,06-1,53)\end{array}$ \\
\hline 2019 & $\begin{array}{l}0,26^{\star \star \star} \\
(0,22-0,31)\end{array}$ & $\begin{array}{l}0,36^{\star \star \star} \\
(0,28-0,46)\end{array}$ & $\begin{array}{l}0,20^{\star \star \star} \\
(0,14-0,29)\end{array}$ & $\begin{array}{l}0,16^{\star \star \star} \\
(0,13-0,20)\end{array}$ & $\begin{array}{l}0,27^{\star \star \star} \\
(0,22-0,32)\end{array}$ & $\begin{array}{l}0,40^{\star \star \star} \\
(0,32-0,49)\end{array}$ & $\begin{array}{l}1,34^{\star \star} \\
(1,11-1,63)\end{array}$ \\
\hline \multicolumn{8}{|c|}{ Model 2} \\
\hline 2003 & Referentie & Referentie & Referentie & Referentie & Referentie & Referentie & Referentie \\
\hline 2007 & $\begin{array}{l}0,72^{\star \star \star} \\
(0,65-0,80)\end{array}$ & $\begin{array}{l}0,87 \\
(0,76-1,00)\end{array}$ & $\begin{array}{l}0,76^{\star \star} \\
(0,63-0,91)\end{array}$ & $\begin{array}{l}0,58^{\star \star \star} \\
(0,49-0,68)\end{array}$ & $\begin{array}{l}0,56^{\star \star \star} \\
(0,50-0,64)\end{array}$ & $\begin{array}{l}0,71^{\star \star \star} \\
(0,63-0,81)\end{array}$ & $\begin{array}{l}1,00 \\
(0,87-1,15)\end{array}$ \\
\hline 2011 & $\begin{array}{l}0,63^{\star \star \star} \\
(0,56-0,70)\end{array}$ & $\begin{array}{l}0,90 \\
(0,78-1,03)\end{array}$ & $\begin{array}{l}0,79^{\star} \\
(0,65-0,95)\end{array}$ & $\begin{array}{l}0,31^{\star \star \star} \\
(0,27-0,36)\end{array}$ & $\begin{array}{l}0,36^{\star \star \star} \\
(0,32-0,41)\end{array}$ & $\begin{array}{l}0,50^{\star \star \star} \\
(0,44-0,57)\end{array}$ & $\begin{array}{l}0,90 \\
(0,78-1,04)\end{array}$ \\
\hline 2015 & $\begin{array}{l}0,37^{\star \star \star} \\
(0,32-0,42)\end{array}$ & $\begin{array}{l}0,52^{\star \star \star} \\
(0,44-0,61)\end{array}$ & $\begin{array}{l}0,37^{\star \star \star} \\
(0,29-0,46)\end{array}$ & $\begin{array}{l}0,12^{\star \star \star} \\
(0,10-0,14)\end{array}$ & $\begin{array}{l}0,19^{\star \star \star} \\
(0,16-0,21)\end{array}$ & $\begin{array}{l}0,32^{\star \star \star} \\
(0,28-0,37)\end{array}$ & $\begin{array}{l}1,03 \\
(0,86-1,24)\end{array}$ \\
\hline 2019 & $\begin{array}{l}0,25^{\star \star \star} \\
(0,22-0,29)\end{array}$ & $\begin{array}{l}0,37^{\star \star \star} \\
(0,30-0,46)\end{array}$ & $\begin{array}{l}0,22^{\star \star \star} \\
(0,16-0,30)\end{array}$ & $\begin{array}{l}0,13^{\star \star \star} \\
(0,11-0,16)\end{array}$ & $\begin{array}{l}0,21^{\star \star \star} \\
(0,18-0,24)\end{array}$ & $\begin{array}{l}0,36^{\star \star \star} \\
(0,31-0,43)\end{array}$ & $\begin{array}{l}1,20^{*} \\
(1,00-1,43)\end{array}$ \\
\hline
\end{tabular}

tendeels te stagneren. De trends zijn voor jongens en meisjes vrijwel hetzelfde, maar de daling is voor jongere leeftijdsgroepen groter dan voor oudere leeftijdsgroepen. Ten slotte worden de waargenomen trends niet verklaard door veranderingen in de samenstelling van de populatie wat betreft opleidingsniveau en migratieachtergrond.

\section{Roken}

Tussen 1999 en 2015 is een forse daling zichtbaar in het gebruik van tabak: het gebruik is meer dan gehalveerd. Dit correspondeert met de aandacht die roken krijgt door een aangepast beleid, de striktere regels van ouders en scholen met betrekking tot roken, en de toenemende pleidooien en acties vanuit maatschappelijke organisaties voor het terugdringen van de zichtbaarheid en beschikbaarheid van de sigaret in onze samenleving. Tussen 2015 en 2019 lijkt de daling echter te stagneren. Naar deze periode kan in meer detail gekeken worden door gegevens van het Health Behaviour in School-aged Children (HBSC)onderzoek uit 2017, binnen de LSM medeverantwoordelijk voor de landelijke kerncijfers over genotmiddelengebruik van twaalf- tot en met zestienjarigen, naast het Peilstationsonderzoek te zetten [23]. Dan valt op dat tussen 2015 en 2017 nog een daling voor roken heeft plaatsgevonden, maar dat de prevalentie onveranderd is tussen 2017 en 2019 [21, 23]. Internationaal zien we eveneens nog tot 2017 een daling in roken, maar een recentere vergelijking is nog niet gemaakt [24]. Het lijkt nog te vroeg om te concluderen dat de dalende tendens voor roken is gestopt en de bodem is bereikt. Het kan gaan om een tijdelijke stagnatie. Wellicht kunnen de activiteiten die vanuit het Nationaal Preventieakkoord zijn ingezet, zoals de accijnsverhoging per 1 april 2020 en het rookvrij maken van alle schoolterreinen per 1 augustus 2020, een nieuwe impuls geven.

\section{Alcoholgebruik}

Het alcoholgebruik is tussen 1999 en 2015 behoorlijk gedaald, vooral tussen 2011 en 2015 was deze daling groot. In die periode is ook veel gebeurd op het gebied van beleid en preventie, zoals aandacht voor de rol van de ouders, de invoering van de leeftijdsgrensverhoging van zestien naar achttien jaar en de start van de socialenormcampagne NIX18, begin 2014. Hoewel de daling in alcoholgebruik onder scholieren al eerder werd ingezet, tussen 2011 en 2013, leek het patroon zich in 2015 voort te zetten [23, 25]. Het alcoholgebruik onder scholieren lijkt sinds 2015 echter op alle fronten gestabiliseerd. Dit bleek eerder ook uit de meting van het HBSC-onderzoek in 2017, zowel nationaal als internationaal [23, 24]. Het lijkt wat betreft alcoholgebruik daarom geen kortdurende of toevallige stagnatie te zijn. 
Wellicht kan ook hier met de activiteiten vanuit het Nationaal Preventieakkoord een nieuwe impuls worden gegeven. Zo is er aandacht voor de toepasbaarheid in Nederland van het zogenaamde IJslandse preventiemodel, een theoriegedreven communityaanpak die succesvol lijkt te zijn in het terugdringen van het middelengebruik onder IJslandse jongeren [26]. Ook wordt momenteel een haalbaarheidsonderzoek uitgevoerd naar Minimum Unit Pricing (MUP) voor alcohol, een prijsmaatregel om overmatig, zwaar een problematisch alcoholgebruik te reduceren. Een dergelijke maatregel die goedkope alcoholhoudende dranken duurder maakt kan juist bij jongeren effectief zijn vanwege hun beperkte inkomsten [27, 28]. Mogelijk helpt een MUP ook om het tij te keren wat betreft het bingedrinken, omdat juist het drinken van grote hoeveelheden dan mogelijk te duur zal worden voor jongeren. Dit is van belang omdat het bingedrinken onder de drinkers in de periode 2003-2019 van $64 \%$ naar $71 \%$ is toegenomen, terwijl in het Nationaal Preventieakkoord voor 2040 een daling naar $45 \%$ is geformuleerd.

\section{Verschillen naar geslacht en leeftijd}

De resultaten laten zien dat meisjes in rook- en drinkgedrag weinig onder doen voor jongens. Er zijn nauwelijks verschillen wat betreft de prevalenties en veranderingen hierin. Omdat ook in de metingen in 1999 en 2003 al weinig verschillen tussen jongens en meisjes zichtbaar waren, wijken de huidige bevindingen af van Europese bevindingen, waar de verschillen tussen jongens en meisjes in de afgelopen decennia kleiner zijn geworden [14]. Gezien de geringe verschillen tussen jongens en meisjes lijken aparte maatregelen voor deze groepen niet nodig.

Voor de verschillende leeftijdsgroepen is dit echter wel wenselijk: naarmate jongeren ouder worden, roken en drinken ze vaker (en meer). Bovendien zijn de waargenomen dalingen in gebruik minder sterk voor de oudere, dan voor de jongere groepen. Dit sluit aan bij eerder internationaal onderzoek $[15,16]$. Om de daling in rook- en drinkgedrag een nieuwe impuls te geven, is het daarom wenselijk om activiteiten te ontwikkelen die zich specifiek richten op deze wat oudere doelgroep (vanaf veertien jaar).

\section{Correctie voor populatiekenmerken}

Volgens gegevens van het CBS zijn ook de kenmerken van scholieren veranderd: het aandeel jongeren met vwo-niveau nam toe, net als het aandeel jongeren met een migratieachtergrond [17]. Dit was ook terug te zien in de steekproeven van het Peilstationsonderzoek. Deze verandering in de bevolkingssamenstelling bood echter geen verklaring voor de gevonden trends: de resultaten bleven grotendeels overeind na correctie voor steekproefkenmerken. Dit versterkt het beeld dat de uitgevoerde activiteiten en maatre- gelen gepaard zijn gegaan met de gewenste ontwikkelingen in gebruik. De bevindingen komen overeen met die van een recent onderzoek uit Nieuw-Zeeland, waarin eveneens een scherpe daling in alcoholgebruik werd gevonden. Deze daling werd ook niet verklaard door veranderingen in de sociaal-demografische kenmerken, maar vooral door een verminderde acceptatie van alcoholgebruik [29]. Ook in Nederland is via bijvoorbeeld NIX18 ingezet op het wijzigen van de sociale norm. Mogelijk zou hier nog sterker op ingezet moeten worden. Ook andere processen kunnen een rol hebben gespeeld bij de daling in gebruik. Internationaal onderzoek concludeert bijvoorbeeld dat de daling in het gebruik van alcohol en tabak in de periode 2002-2014 samenhangt met een daling in de mate waarin jongeren elkaar in hun vrije tijd fysiek ontmoeten [30].

\section{Sterke kanten en beperkingen}

Het Peilstationsonderzoek Scholieren maakt gebruik van een stabiele onderzoeksmethode én beschikt over representatieve steekproeven van alle scholieren van het reguliere voortgezet onderwijs. Hierdoor maakt het onderzoek het niet alleen mogelijk om de huidige situatie te duiden, maar ook om vergelijkingen over de jaren heen te maken.

Een aantal beperkingen van het onderzoek moet genoemd worden. Ten eerste betreft het steeds crosssectionele data, waardoor het niet mogelijk is om oorzakelijke verbanden aan te tonen met bijvoorbeeld het gevoerde beleid. De cijfers kunnen wel laten zien of de maatregelen gepaard gaan met de gewenste ontwikkelingen in gebruik. Ten tweede wijkt het Peilstationsonderzoek uit 1999 af van de onderzoeken uit 2003 en later vanwege het ontbreken van een random steekproeftrekking. De steekproef bleek in 1999 niet geheel representatief te zijn (de middencategorie van stedelijkheid was ondervertegenwoordigd), maar na weging waren er geen verschillen meer met de landelijke CBSgegevens [31]. Het is daarom niet waarschijnlijk dat dit een groot effect heeft op de resultaten. Ten derde is het de afgelopen decennia steeds lastiger geworden scholen te overtuigen van deelname aan het onderzoek. Dit is een uitdaging waar veel Nederlandse, maar ook internationale, onderzoeken mee te maken hebben [32]. De lagere respons op schoolniveau kan een negatieve invloed hebben op de representativiteit van het onderzoek. De respons op leerlingniveau blijft echter hoog en de afwijking tussen de steekproef en de landelijke verdeling volgens het CBS is steeds klein. Dit duidt erop dat de representativiteit van het onderzoek nog altijd goed is. Ook simulatieonderzoek wijst erop dat ondanks een relatief hoge non-respons van scholen, surveyonderzoek naar middelengebruik nog steeds valide prevalentieschattingen kan geven [32]. 


\section{Conclusies en implicaties}

$\mathrm{Na}$ jaren van forse dalingen in het gebruik van tabak en alcohol door scholieren van twaalf tot en met zestien jaar, stagneert deze daling sinds 2015. Wellicht gaan de activiteiten in het kader van het Nationale Preventieakkoord de komende jaren voor een nieuwe impuls zorgen. Toekomstige metingen moeten dat uitwijzen. Daarbij is vooral een focus op de oudere leeftijdsgroep nodig. Zo is, ondanks de leeftijdsgrens van achttien jaar voor de verkoop van tabak en alcohol, het gebruik onder de vijftien- en zestienjarigen nog altijd fors. Ten slotte wijzen de huidige bevindingen op de noodzaak van een sterke inzet op het verminderen van bingedrinken onder degenen die drinken.

Open Access This article is licensed under a Creative Commons Attribution 4.0 International License, which permits use, sharing, adaptation, distribution and reproduction in any medium or format, as long as you give appropriate credit to the original author(s) and the source, provide a link to the Creative Commons licence, and indicate if changes were made. The images or other third party material in this article are included in the article's Creative Commons licence, unless indicated otherwise in a credit line to the material. If material is not included in the article's Creative Commons licence and your intended use is not permitted by statutory regulation or exceeds the permitted use, you will need to obtain permission directly from the copyright holder. To view a copy of this licence, visit http://creativecommons.org/licenses/by/4.0/.

\section{Literatuur}

1. Ewing SWF, Sakhardande A, Blakemore S-J. The effect of alcohol consumption on the adolescent brain: a systematic review of MRI and fMRI studies of alcohol-using youth. Neuroimage Clin. 2014;5:420-37.

2. De Hersenstichting. Puberhersenen in ontwikkeling. Den Haag: DeHersenstichting; 2017.

3. Carbia C, López-Caneda E, Corral M, et al. A systematic reviewofneuropsychologicalstudiesinvolvingyoungbinge drinkers. Neurosci Biobehav Rev. 2018;90:332-49.

4. Mokdad AH, Forouzanfar MH, Daoud F, et al. Global burden of diseases, injuries, and risk factors for young people's health during 1990-2013: a systematic analysis for the Global Burden of Disease Study 2013. Lancet. 2016;387:2383-401.

5. National Institute on Alcohol Abuse and Alcoholism (NIAAA). Underage drinking. 2020. www.niaaa.nih.gov. Geraadpleegd op 1 juni2020.

6. Fanshawe TR, Halliwell W, Lindson N, et al. Tobacco cessation interventions for young people. Cochrane Database Syst Rev. 2017; https://doi.org/10.1002/14651858. CD003289.pub6.

7. Tobacco Etiology Research Network (TERN), Dierker L, Swendsen J, Rose J, et al. Transitions to regular smoking and nicotine dependence in the Adolescent National Comorbidity Survey (NCS-A). Ann Behav Med. 2012;43:394-401.

8. Yap MBH, Cheong TWK, Zaravinos-Tsakos F, et al. Modifiable parenting factors associated with adolescent alcohol misuse: a systematic review and meta-analysis oflongitudinal studies. Addiction. 2017;112:1142-62.

9. Sharmin S, Kypri K, Khanam M, et al. Effects of parental alcohol rules on risky drinking and related problems in adolescence: systematic review and meta-analysis. Drug AlcoholDepend. 2017;178:243-56.

10. Hartstichting, KWFkankerbestrijding, Longfonds. Rookvrij opgroeien. Geraadpleegd op 1 juni 2020.

11. Monshouwer K, Verdurmen J, Laar Mvan. Factsheet display ban verkooppunten tabak. Utrecht: Trimbos-instituut; 2015.

12. Rijksoverheid. Nationaal Preventieakkoord. 2018. pag. 1-76.

13. Shibuya K, Ciecierski C, Guindon E, et al. WHO framework convention on tobacco control: development of an evidence based global public health treaty. $\mathrm{Br}$ Med J. 2003;327:154-7.

14. Kraus L, Seitz N-N, Piontek D, et al. 'Are The Times A-Changin'? Trends in adolescent substance use in Europe. Addiction. 2018;113:1317-32.

15. Schelleman-OffermansK, RoodbeenRTJ,LemmensPHHM Increased minimum legal age for the sale of alcohol in the Netherlands as of 2014: the effect on alcohol sellers' compliance after one and two years. Int J Drug Policy. 2017;49:8-14.

16. Williams TP, Lillis RP. Long-term changes in reported alcohol purchasing and consumption following an increase in New York State's purchase age to 19 . $\mathrm{Br}$ J Addict. 1988;83:209-17.

17. Centraal Bureau voor de Statistiek. Centraal Bureau voor de Statistiek. Jaarrapport landelijke jeugdmonitor. Den Haag: Centraal Bureau voor de Statistiek; 2019.

18. Tuithof M, Dorsselaer S van, Monshouwer K. Veranderingen in middelengebruik onder Nederlandse scholieren: samenhang met schoolniveau. Utrecht: Trimbos-instituut; 2017.

19. Centraal Bureau voor de Statistiek. Centraal Bureau voor de Statistiek. Jaarrapport landelijke jeugdmonitor. Den Haag: Centraal Bureau voor de Statistiek; 2018.

20. Van Amsterdam JGC, Benschop A, Binnendijk S van, et al. A comparison of excessive drinking, binge drinking and alcohol dependence in ethnic minority groups in the Netherlands: the HELIUS study. Eur AddictRes. 2020;26:66-76.

21. Rombouts M, Dorsselaer S van, Scheffers-van Schayck T, et al. Jeugd en riskant gedrag 2019. Kerngegevens uit het Peilstationsonderzoek Scholieren. Utrecht: Trimbosinstituut; 2020.

22. Kramers P,BergMvanden, BrinkCvanden, etal. Monitoring van leefstijl in Nederland: een traject voor verbetering. Bilthoven: RIVM;2012.

23. Stevens G, Dorsselaer S van, Boer M, et al. HBSC 2017. Gezondheid, welzijn en de sociale context van scholieren in Nederland. Utrecht: Universiteit Utrecht; 2018.

24. World Health Organization. Spotlight on adolescent health and well-being. band 1. Geneva: World Health Organization; 2018. pag. 58.

25. Looze M de, Dorsselaer S van, Roos S de, et al. HBSC 2013. Gezondheid, welzijn en opvoeding van jongeren in Nederland. Utrecht: Universiteit Utrecht; 2014.

26. Arnarsson A, Kristofersson GK, Bjarnason T. Adolescent alcohol and cannabis use in Iceland 1995-2015. Drug Alcohol Rev. 2018;37:S49-S57.

27. Holmes J, Meier PS, Angus C, et al. Scotland's policy on minimum unit pricing for alcohol: the legal barriers are gone, so what are the implications for implementation and evaluation? Addiction. 2018;113:203-4.

28. Wit G de, Visscher K, Gelder N van, et al. Minimum Unit Pricing voor alcohol - verkenning van effectiviteit , implementatieaspecten en scenario 's voor prijsbeleid in. Bilthoven: Rijksoverheid;2020. 
29. Ball J, Edwards R, Sim D, et al. What explains the decline in adolescent binge-drinking in New Zealand? Int J Drug Policy. 2020;84:102826.

30. Looze M de, Dorsselaer S van, Stevens GWJM, et al. The decline in adolescent substance use across Europe and North America in the early twenty-first century: a result of the digital revolution? Int J Public Health. 2019;64:229-40.
31. Zwart WM de, Monshouwer K, Smit F. Jeugd en riskant gedrag: kerngegevens 1999. Utrecht: Trimbos-instituut; 2000.

32. Thrul J, Pabst A, Kraus L. The impact of school nonresponse on substance use prevalence estimates-Germany as a case study. Int J Drug Policy. 2016;27:164-72. 